The University of Maine

DigitalCommons@UMaine

$12-1998$

Racial prejudice and support by whites for police use of force : A research note

Steven E. Barkan

Steven F. Cohn

Follow this and additional works at: https://digitalcommons.library.umaine.edu/soc_facpub

Part of the Inequality and Stratification Commons, Politics and Social Change Commons, Race and Ethnicity Commons, and the Social Control, Law, Crime, and Deviance Commons

This Article is brought to you for free and open access by DigitalCommons@UMaine. It has been accepted for inclusion in Sociology School Faculty Scholarship by an authorized administrator of DigitalCommons@UMaine. For more information, please contact um.library.technical.services@maine.edu. 


\title{
RACIAL PREJUDICE AND SUPPORT BY WHITES FOR POLICE USE OF FORCE: A RESEARCH NOTE
}

\author{
STEVEN E. BARKAN \\ STEVEN F. COHN \\ University of Maine
}

\begin{abstract}
The use of force by police in a democratic society continues to be controversial. Despite the theoretical and practical importance of police use of force, little is known about the sources of public attitudes toward it. Recent research suggests that whites' approval of police use of force may derive partly from racial prejudice against African Americans. In this paper we test this possibility with data from the 1990 General Social Survey and find that negative stereotypes of African Americans contribute to whites' support for police use of excessive force. We also address the theoretical and pragmatic significance of our findings.
\end{abstract}

One of the most important but most controversial powers of police in a democratic society is the use of force (Bittner 1970; Skolnick and Fyfe 1993; Westley 1953). Police are authorized to use physical violence when necessary, but police brutality, or the undue use of force, remains a serious problem in the United States, especially for African Americans and other urban residents (Dudley 1991; Kappeler, Sluder, and Alpert 1994; Skolnick and Fyfe 1993). Perceptions of police brutality appear to be a major source of dissatisfaction with police among these citizens (Holmes 1991; Saad and McAneny 1995; Wilkerson 1992).

Public opinion polls document racial differences in attitudes toward police use of force: African Americans are more likely than whites to hold unfavorable views (Flanagan and Vaughn 1995; Huang and Vaughn 1996; Williams, Thomas, and Singh 1983). Surprisingly few researchers, however, have attempted to explain these differences. In a recent exception, Cullen et al. (1996) examined racial differences among Cincinnati residents in support for police use of deadly force. They found that whites were more likely than African Americans to support such use, and attributed this finding to ideological differences between the two races on crime 
and its control. Even so, more research on racial differences in attitudes toward police use of force, both deadly and nondeadly, is needed if we are to consider other possible determinants of racial differences.

In explaining whites' approval of police use of force, recent work on support by whites for the punitive treatment of criminals suggests an important avenue for investigation. Using data from national surveys of U.S. residents, Barkan and Cohn (Barkan and Cohn 1994; Cohn, Barkan, and Halteman 1991) found in multivariate analyses that prejudice against African Americans predicted whites' support both for harsher sentencing of criminals and for capital punishment (also see Aquirre and Baker 1993).

These results support a conflict perspective on race, crime, and society (Bohm 1982; Lynch and Groves 1989; Turk 1969). In this view, the legal system is a means for the social control of subordinate races and other groups. Despite historical evidence of such control (Myers 1990; Tolnay and Beck 1995), there is considerable debate about whether the legal system works in this manner today (Mann 1993; Walker, Spohn, and DeLone 1996; Wilbanks 1987). Still, many whites perceive criminals as disproportionately African American and members of other minority groups (Doleschal 1979; Smith 1991). Because racial prejudice often stems from whites' vested interest in maintaining their social and political dominance (Blalock 1967; Bonacich 1972, 1980), such prejudice among whites should increase their desire for harsh criminal sanctions.

Although Barkan and Cohn's (1994; Cohn et al. 1991) research supported this perspective, it was incomplete in at least one important respect: It did not specify the conditions under which prejudice would be more or less likely to affect preferred legal outcomes. What are these conditions? To begin to answer this question, we suggest that the effects of individual-level variables (including but not limited to racial prejudice) will be greater when the appropriateness of legal sanctions is unclear. Whether or not people in privileged positions have the most to lose from crime (Lynch and Groves 1989), all people have an interest in not becoming crime victims; thus everyone except criminals has an interest in seeing the crime rate reduced. If this is true, people generally should wish to see criminals punished where clear evidence of guilt exists and where it is generally agreed that the legally prescribed sanctions are reasonable punishment for the offense. Therefore, the effects of personal sentiments and attitudes should be attenuated in these situations, but should be more apparent in situations where legal sanctions are considered excessive or inappropriate. 
In regard to racial prejudice, this argument is supported indirectly by two related literatures. The first involves research testing the "liberation hypothesis," originally advanced by Kalven and Zeisel (1966) in their classic study of jury behavior. Kalven and Zeisel found juries more likely to let their beliefs and values influence their decision making when the evidence against defendants was weak than when it was strong. In effect, weak evidence "liberated" jurors to look beyond the law in reaching verdicts. Several studies since then have found that race and other extralegal variables influence decision making by juries, judges, and prosecutors more often in weak cases than in strong cases, and more often in less serious than in more serious crimes (Baldus, Woodworth, and Pulaski 1985; Barnett 1985; Reskin and Visher 1986; Spohn and Cederblom 1991; Unnever and Hembroff 1988). The idea here is that the strongest and most serious cases leave little room for discretion to affect decisions. Other cases permit more discretion and increase the opportunity for racial bias and other extralegal factors to play a role.

The second source of support for our argument comes from the field of social psychology. In explaining racial prejudice, Gaertner and Dovidio (1986) distinguish dominative from aversive racism. In dominative racism, which they believe was more characteristic of earlier periods of U.S. history, whites hold racially prejudiced attitudes and do not apply norms of equity to African Americans. White dominative racists thus would be expected to discriminate against African Americans in all situations. In aversive racism, which Gaertner and Dovidio believe is more characteristic of the United States today, whites hold conflicting attitudes toward African Americans: Although they are racially prejudiced, they also believe in fairness and equity. White aversive racists thus would not be expected to discriminate in situations where norms of equity clearly applied, but would be expected to do so in situations where applicability of these norms was less clear.

These two literatures have an important implication for a link, among whites, between racial prejudice and punitive attitudes, and thus for a possible link between racial prejudice and support for police use of force. Prejudice should affect punitiveness more strongly under two conditions: (1) when the case against a suspect or defendant is relatively weak, and (2) when the offender's alleged wrongdoing is less serious. Specifically, racial prejudice among whites should affect their support for police use of force more strongly when the suspect's conduct is not perceived as meriting such force (i.e., when such force is considered excessive) than when 
the suspect's conduct is so perceived (i.e., when such force is considered reasonable). We test this hypothesis below.

\section{THE STUDY}

Our data come from the 1990 wave of the General Social Survey (GSS). The GSS is a national multistage probability sample of the noninstitutionalized English-speaking U.S. population conducted regularly since 1972 by the National Opinion Research Center. The 1990 GSS included a special module and other items on racial prejudice that make it a desirable data set for this analysis (Barkan and Cohn 1994). We restrict our analysis to whites because they are the focus of our theoretical discussion.

The 1990 GSS contains four items measuring attitudes toward police use of force. Respondents were asked to indicate whether they would approve of a "policeman striking an adult male citizen" if the citizen (a) "had said vulgar and obscene things to the policeman"; (b) "was being questioned as a suspect in a murder case"; (c) "was attempting to escape from custody"; and (d) "was attacking the policeman with his fists." A factor analysis distinguished items (a) and (b) from items (c) and (d). As indicated by the responses to these items reported in Table 1, this distinction appears to be based on whether respondents approved of police use of force in the particular situation. Most people in the GSS sample disapproved of police violence in the situations represented by (a) and (b) and approved of police violence in the situations represented by (c) and (d). In the public's judgment, then, the use of police force in the first two circumstances would be excessive, while the use of force in the final two circumstances would be reasonable. ${ }^{1}$ Our theoretical discussion thus would predict that racial prejudice should be related to

Table 1. Support by Whites for Police Use of Force, 1990 General Social Survey

Percent Approving

Use of Force

Item

(Number of Respondents)

\begin{tabular}{lll}
\hline (a) Saying Vulgar and Obscene Things & $12(717)$ \\
(b) Suspect in Murder Case & $10 \quad(720)$ \\
(c) Attempting to Escape from Custody & $80 \quad(709)$ \\
(d) Attacking Policeman with Fists & $95 \quad(733)$
\end{tabular}

1 The U.S. Supreme Court outlined the legal standard for reasonable use of force in Graham v. Connor (1989). Earlier, in Tennessee v. Garner (1985), the Court had prohibited the use of deadly force against nonviolent felons attempting to escape custody. 
police use of force more strongly in the first pair of circumstances than in the second pair.

Accordingly we added responses to the two pairs of items to form two separate scales of approval for police use of force: excessive force (alpha reliability $=.56$ ) and reasonable force (alpha $=.58$ ). Because of the skewness in each scale, we combined respondents in the excessive force scale who said "yes" to either or both of the items making up the scale (16\%) and compared them ("approve" category) in the multivariate analysis with those who said "no" to both items (84\%). Similarly, we combined respondents in the reasonable force scale who said "no" to either or both of the items making up the scale (21\%) and compared them with those who said "yes" to both items ("approve" category, 79\%).

Two measures of racial prejudice are included in the analysis; both measures predicted support for the death penalty among whites in Barkan and Cohn's (1994) earlier study, net of other factors. The first measure, antipathy to blacks, is a scale of two items asking respondents to indicate how strongly they favored or opposed "living in a neighborhood where half your neighbors were Blacks," and "having a close relative or family member marry a Black person" (alpha $=.67$ ) The second measure, racial stereotyping, is a scale of four items that asked respondents to indicate on seven-point scales the degree to which they thought blacks were lazy, unintelligent, desirous of living off welfare, and unpatriotic (alpha =.62). A factor analysis distinguished the items in the stereotyping scale from those in the antipathy scale; the correlation of the two scales (Pearson's $r$ ) was .35.

We included several other variables as controls for spuriousness. The first is political conservatism, a standard GSS item asking respondents to rate themselves on a seven-point scale. In prior research, conservatism predicted support for various measures of the social control of criminals (Gerber and Engelhardt-Greer 1996; Langworthy and Whitehead 1986; Young 1992), including police use of force (Cullen et al. 1996; Huang and Vaughn 1996). Another variable, membership in a fundamentalist church, was suggested by previous work linking fundamentalism to retributive attitudes (Ellison and Sherkat 1993; Grasmick et al. 1992). We also considered it advisable to include a third variable, fear of crime, which some (but not all) studies have found related to support for punitive treatment of criminals (Cullen et al. 1985; Langworthy and Whitehead 1986). This variable is a standard GSS measure asking respondents whether there is "any area right around here-that is, within a mile-where you would be afraid to walk alone at night" (1 $=$ yes, $0=$ no). 
Three additional variables-education, age, and gender-also have been linked to punitiveness, which generally decreases with education and increases with age, and is greater for men than for women (Stinchcombe et al. 1980). Partly in accordance with these patterns, a recent national survey found that education was associated negatively and age was associated positively with favorable attitudes toward police use of force, but discovered no differences between women and men (Huang and Vaughn 1996). Given the historic evidence of racial prejudice in the south, we also included southern residence as a control variable. Finally, we included the population size of the respondents' place of interview, in view of the greater police presence and higher crime rates in urban areas.

\section{RESULTS}

Table 2 presents the bivariate correlations (Pearson's $r$ ) of each predictor variable with the two measures of support for police use of force. Both measures of racial prejudice are associated positively with support for both types of police use of force.

\section{Table 2. Correlations (Pearson's $r$ ) of Predictor Variables with Two Measures of Police Use of Force, 1990 General Social Survey}

\begin{tabular}{lllll}
\hline & \multicolumn{4}{c}{ Coefficients } \\
(Number of Cases) \\
\cline { 2 - 5 } Independent Variables & \multicolumn{3}{c}{ Excessive Force } & \multicolumn{1}{c}{ Reasonable Force } \\
\hline Antipathy to Blacks & $.19^{* * *}$ & $(692)$ & $.15^{* *}$ & $(696)$ \\
Racial Stereotyping & $.12^{* *}$ & $(652)$ & $.07^{*}$ & $(654)$ \\
Political Conservatism & $.07^{*}$ & $(681)$ & $.08^{*}$ & $(684)$ \\
Fundamentalist Church & $.13^{* *}$ & $(676)$ & $.09^{* *}$ & $(680)$ \\
Fear of Crime & $.11^{*}$ & $(345)$ & -.02 & $(352)$ \\
Education & $-.11^{* *}$ & $(703)$ & .02 & $(706)$ \\
Age & $.12^{* *}$ & $(704)$ & .04 & $(707)$ \\
Gender (1=Male) & $.07^{*}$ & $(704)$ & $.14^{* * *}$ & $(707)$ \\
Southern Residence & $.07^{*}$ & $(704)$ & $.07^{*}$ & $(707)$ \\
Population Size & .01 & $(704)$ & .04 & $(707)$ \\
\hline
\end{tabular}

${ }^{*} p<.05 ;{ }^{* *} p<.01 ; * * * p<.001 ;$ one-tailed tests

Support for both types is also higher among respondents who are politically conservative, members of fundamentalist churches, men, and southerners. Education is associated negatively and age is associated positively with support for excessive force, but neither is associated with support for reasonable force.

Because each scale of approval of police use of force was dichotomous, logistic regression is an appropriate statistical technique for 
multivariate analysis. The results of our logistic regression analyses appear in Table $3 .^{2}$ Four variables show independent effects on support for police use of excessive force. As hypothesized, whites who accept racial stereotypes of African Americans are more likely to approve of excessive force, net of all other factors. The "antipathy to blacks" measure of racial prejudice, however, does not predict such approval. Of the remaining variables, approval is higher among whites who belong to fundamentalist churches, who fear walking outside their homes at night, and who are male. In results not included in the table, the independent effect of the stereotyping scale on approval of excessive force was higher $(r=.10)$ than that of any of the other three variables predicting approval. In the analysis for the reasonable force scale, no variable independently affects whites' support for police use of such force. Overall the results support our hypothesis that racial prejudice contributes to whites' support for police use of force, and that this relationship should be stronger for the use of excessive force than for the use of reasonable force.

\section{Table 3. Logistic Regression of Whites' Support for Two Measures of Police Use of Force, 1990 General Social Survey (Unstandardized Coefficients)}

\begin{tabular}{lcc}
\hline & \multicolumn{2}{c}{ Coefficients } \\
\cline { 2 - 3 } Independent Variables & Excessive Force & Reasonable Force \\
\hline Antipathy to Blacks & .14 & .08 \\
Racial Stereotyping & $.14^{*}$ & .05 \\
Political Conservatism & .12 & .08 \\
Fundamentalist Church & $.75^{*}$ & .46 \\
Fear of Crime & $.66^{*}$ & -.40 \\
Education & -.06 & .03 \\
Age & .01 & .01 \\
Gender (1=Male) & $.64^{*}$ & .17 \\
Southern Residence & -.19 & .56 \\
Population Size & .00 & .00 \\
Constant & -5.95 & -1.30 \\
Goodness of Fit & 299.61 & 297.50 \\
Number of Cases & 299 & 302 \\
\hline
\end{tabular}

$* p<.05 ;$ one-tailed tests

2 Although the 1990 GSS included 1,150 whites, only about 300 remain in the analyses reported in Table 3 . This reduction occurred primarily because the primary measures used in our analyses were given only to split samples, as indicated by the number of cases listed in Tables 1 and 2. The subsample receiving the "fear of crime" item was smaller than those given the other items (see Table 2), and especially helped to reduce the number of cases remaining in the multivariate analyses presented in Table 3 . Although the number of whites in Table 3 is thus smaller than the number of whites in the entire 1990 GSS, the cases in Table 3 remain a random sample. Thus the results of this table are generalizable to the national population represented by the GSS. 


\section{DISCUSSION AND CONCLUSION}

Drawing on several literatures, we predicted that racial prejudice among whites should be associated with their support for police use of excessive force. Although our scale of approval for such force does not include all the possible situations in which it is used, our results indicate that racial prejudice in fact contributes to whites' approval of such behavior. This finding has important theoretical and policy implications.

Theoretically, our results indicate that previous findings linking racial prejudice to whites' support for harsher court sanctions and for the death penalty (Aguirre and Baker 1993; Barkan and Cohn 1994; Cohn et al. 1991) may be extended to the use of force by the police, at least in the circumstances covered here. Future research should test our hypothesis against many of the other circumstances in which excessive force is used. Further, our results, in accordance with our predictions following the liberation hypothesis and the distinction between dominative and aversive racism, help to specify the conditions under which racial prejudice affects approval of such force: Racial prejudice increases whites' support for the use of excessive force by police, but not for the use of reasonable force. Again, future research should test this hypothesis against the many circumstances in which either type of force is used. Our study thus complements findings of racially based outcomes from previous research grounded in the liberation hypothesis (Spohn and Cederblom 1991).

As for policy implications, in discussing concern about crime in the United States, observers often argue that crime is a code word for race (Edsall and Edsall 1991; Hacker 1992; LaFree 1995; Skogan 1995). Despite the assumption that public concern about crime partly reflects whites' prejudice against African Americans, few researchers have tested whether this is the case. In studies of national (GSS) data, however, Skogan (1995) recently found racial prejudice among whites linked to their fear of crime, and Barkan and Cohn (1994; Cohn et al. 1991) found that racial prejudice motivated whites' approval for the harsher sentencing of criminals and for the death penalty. In the present study we have learned that prejudice also motivates whites' approval of excessive police violence.

This set of findings supports assumptions that prejudice against African Americans partially underlies public (i.e., whites') calls for harsher treatment of criminals. In a democratic society it is unacceptable for racial prejudice to guide public policy. Insofar as racial prejudice motivates calls by the public and perhaps by 
public officials for the harsher treatment of criminals, such treatment is unjustified. Our study and the work of Skogan (1995) and Barkan and Cohn (1994; Cohn et al. 1991) provide grounds for resisting such calls.

Given the theoretical and practical importance of police use of force, additional investigations of public views on such behavior are essential. These investigations would benefit from more comprehensive measures of the use of both excessive and reasonable force. More generally, our results reinforce the need for research on racial bias in public attitudes about crime and punishment, and in criminal justice outcomes, to specify the conditions under which such bias might or might not appear.

\section{REFERENCES}

Aguirre, A. and D.V. Baker. 1993. "Racial Prejudice and the Death Penalty: A Research Note." Social fustice 20:150-55.

Baldus, D.C., G. Woodworth, and C. Pulaski. 1985. "Monitoring and Evaluating Contemporary Death Sentencing Systems: Lessons from Georgia." U.C. Davis Law Review 18:1375-1407.

Barkan, S.E. and S.F. Cohn. 1994. "Racial Prejudice and Support for the Death Penalty by Whites." Journal of Research in Crime and Delinquency 31:202-209.

Barnett, A. 1985. "Some Distribution Patterns for the Georgia Death Sentence." U.C. Davis Law Review 18:1327-74.

Bittner, E. 1970. The Functions of the Police in Modern Society. Rockville, MD: National Institute of Mental Health.

Blalock, H. 1967. Toward a Theory of Minority-Group Relations. New York: Wiley.

Bohm, R.M. 1982. "Radical Criminology: An Explication." Criminology 19:565-89.

Bonacich, E. 1972. "A Theory of Ethnic Antagonism: The Split-Labor Market." American Sociological Review 37:547-59.

— 1980. "Class Approaches to Ethnicity and Race." Insurgent Sociologist 10:923.

Cohn, S.F., S.E. Barkan, and W.A. Halteman. 1991. "Punitive Attitudes toward Criminals: Racial Consensus or Racial Conflict?" Social Problems 38:287-96.

Cullen, F.T., L. Cao, R.H. Langworthy, S.L. Browning, R. Kopeche, and T.J. Stevenson. 1996. "Stop or I'll Shoot': Racial Differences in Support for Police Use of Deadly Force." American Behavioral Scientist 39:449-60.

Cullen, F.T., G.A. Clark, J.B. Cullen, and R.A. Mathers. 1985. "Attribution, Salience, and Attitudes toward Criminal Sentencing." Criminal Justice and Behavior 12:305-31.

Doleschal, E. 1979. "Crime: Some Popular Beliefs." Crime and Delinquency 25:1-8.

Dudley, W., ed. 1991. Police Brutality. San Diego: Greenhaven.

Edsall, T.B. and M.D. Edsall. 1991. "When the Official Subject Is Presidential Polities, Taxes, Welfare, Crime, Rights, or Values . . the Real Subject is Race." Atlantic Monthly, May, pp. 53-73.

Ellison, C.G. and D.E. Sherkat. 1993. "Conservative Protestantism and Support for Corporal Punishment." American Sociological Review 58:131-44.

Flanagan, T.J. and M.S. Vaughn. 1995. "Public Opinion about Police Abuse of Force." Pp. 113-31 in And Justice for All: Understanding and Controlling Police Abuse of Force, edited by W.A. Geller and H. Toch. Washington, DC: Police Executive Research Forum.

Gaertner, S.L. and J.F. Dovidio. 1986. “The Aversive Form of Racism." Pp. 61-90 in Prejudice, Discrimination, and Racism, edited by J.F. Dovidio and S.L. Gaertner. New York: Academic Press. 
Gerber, J. and S. Engelhardt-Greer. 1996. "Just and Painful: Attitudes toward Sentencing criminals." Pp. 72-74 in Americans View Crime and Justice: A National Public Opinion Survey, edited by T.J. Flanagan and D.R. Longmire. Thousand Oaks, CA: Sage.

Grasmick, H.G., E. Davenport, M.B. Chamlin, and R.J. Bursik Jr. 1992. "Protestant Fundamentalism and the Retributive Doctrine of Punishment." Criminology $30: 21-45$.

Haceker, A. 1992. Two Nations: Black and White, Separate, Hostile, Unequal. New York: Scribner's.

Holmes, S.A. 1991. "Poll on Police Finds Satisfaction but Race Division." New York Times, April 5, p. A11.

Huang, W.S.W. and M.S. Vaughn. 1996. "Support and Confidence: Public Attitudes toward the Police." Pp. 31-45 in Americans View Crime and Justice: A National Public Opinion Survey, edited by T.J. Flanagan and D.R. Longmire. Thousand Oaks, CA: Sage.

Kalven, H. and H. Zeisel, 1966. The American Jury. Boston: Little, Brown.

Kappeler, V.E., R.D. Sluder, and G.P. Alpert. 1994. Forces of Deviance: Understanding the Dark Side of Policing. Prospect Heights, IL: Waveland.

LaFree, G. 1995. "Race and Crime Trends in the United States, 1946-1990." Pp. 169-93 in Ethnicity, Race, and Crime: Perspectives across Time and Place, edited by D.F. Hawkins. Albany: SUNY Press.

Langworthy, R.H. and J.T. Whitehead. 1986. "Liberalism and Fear as Explanations of Punitiveness." Criminology 24:575-91.

Lynch, M.J. and W.B. Groves. 1989. A Primer in Radical Criminology. Albany: Harrow and Heston.

Mann, C.R. 1993. Unequal Justice: A Question of Color. Bloomington: Indiana University Press.

Myers, M.A. 1990. "Economic Threat and Racial Disparities in Inearceration: The Case of Postbellum Georgia." Criminology 28:627-56.

Reskin, B.F. and C.A. Visher. 1986. "The Impacts of Evidence and Extralegal Factors in Jurors' Decisions." Law and Society Review 20:423-38.

Saad, L. and L. McAneny, 1995. "Black Americans See Little Justice for Themselves: And Most Believe Simpson Not Guilty." Gallup Poll Monthly (March):3235 .

Skogan, W.G. 1995. "Crime and the Racial Fears of White Americans." Annals of the American Academy of Political and Social Sciences 539:59-71.

Skolnick, J.H, and J. Fyfe. 1993. Above the Law: Police and the Excessive Use of Force. New York: Free Press.

Smith, T.W. 1991. "Ethnic Images in the United States." The Polling Report 7:1-8.

Spohn, C. and J. Cederblom. 1991. "Race and Disparities in Sentencing: A Test of the Liberation Hypothesis." Justice Quarterly 8:305-27.

Stinchcombe, A.L., R. Adams, C.A. Heimer, K.L. Scheppele, T.W. Smith, and D.G. Taylor. 1980. Crime and Punishment: Changing Attitudes in America. San Francisco: Jossey-Bass.

Tolnay, S.E. and E.M. Beck. 1995. A Festival of Violence: An Analysis of Southern Lynchings, 1882-1930. Urbana: University of Illinois Press.

Turk, A.T. 1969. Criminality and Legal Order. Chicago: Rand McNally.

Unnever, J.D. and L.A. Hembroff. 1988. "The Prediction of Racial/Ethnic Sentencing Disparities: An Expectation States Approach." Journal of Research in Crime and Delinquency 25:53-82.

Walker, S., C. Spohn, and M. DeLone. 1996. The Color of Justice: Race, Ethnicity, and Crime in America. Belmont, $\mathrm{CA}$ : Wadsworth.

Westley, W.A. 1953. "Violence and the Police." American Journal of Sociology 59:34-41.

Wilbanks, W. 1987. The Myth of a Racist Criminal Justice System. Monterey, CA: Brooks/Cole.

Wilkerson, I. 1992. "Acquittal in Beating Raises Fears over Race Relations." New York Times, May 1, p. A13.

Williams, J.S., C.W. Thomas, and B.K. Singh. 1983. "Situational Use of Police Force: Public Relations." American Journal of Police 3:37-50.

Young, R.L. 1992. "Religious Orientation, Race and Support for the Death Penalty." Journal for the Scientific Study of Religion 31:76-87. 


\section{CASES CITED}

Graham v. Connor, 490 U.S. 396 (1989).

Tennessee v. Garner, 471 U.S. 1 (1985). 